\title{
Human Induced Land Use/ Land Cover Changes in Northern Part of Gurgaon District, Haryana, India: Natural Resources Census Concept
}

\author{
B. S. Chaudhary, G. P. Saroha* and Manoj Yadav* \\ Department of Geophysics, Kurukshetra University, Kurukshetra136 119, Haryana, India \\ E-mail: bsgeokuk@gmail.com \\ *Haryana State Remote Sensing Application Centre (HARSAC), Hisar 125 004, \\ Haryana, India
}

KEYWORDS Remote Sensing. GIS. Land Use/ Land Cover. Change Detection. Hotspots

\begin{abstract}
There is tremendous pressure on the natural resources due to increasing population. To meet the demands of large population means the need for more food production, more requirement of energy, more water requirement, better civic amenities for a reasonable quality of urban life, more infrastructure development to sustain increasing pressure and increased per-capita expenditure for maintaining quality of life. Land resources being finite imply more judicious use of land resources to meet the ever-increasing demands. The unsustainable and unplanned exploitation of land resources is the major reason for degradation of our environment. The main issue is to bring a balance between economic development and conservation of resources, which is possible by proper inventory, and management of these resources on periodic basis. Recent technologies of Remote Sensing (RS) and Geographic Information System (GIS) have made it feasible and cost effective. Present study deals with RS and GIS based monitoring of land use/ land cover changes in northern part of Gurgaon District, Haryana. Total area under study is about 697 sq. km. IRS 1B LISS II satellite data paper prints of August 1996 and February 1997 and IRS-IC/ ID LISS-III digital data of August/ September 2001, February 2002 and June 2002 were used. This data was analyzed in GIS environment. It is found that there is maximum increase in the area under settlements, which has increased almost four times over this period. The double crop area showed a decline however there as an increase in the area under closed forest. The wasteland has also decreased drastically due to its conversion to Settlements and other categories. The causes of these changes have also been analyzed.
\end{abstract}

\section{INTRODUCTION}

To meet the demands of large population means the need for more food production, more requirement of energy, more water requirement, better civic amenities for a reasonable quality of urban life, more infrastructure development to sustain increasing pressure and increased percapita expenditure for maintaining quality of life. This requires prudent use of land use/ land cover in the area. Land use refers to "man's activities and various uses, which are carried on land (such as agriculture, settlements, industry etc)". Land cover refers to the material present e.g. vegetation, water bodies, rocks/soils and other resulting from land transformations. Although land use is generally inferred based on the cover, yet both the terms land use and land cover being

Address for correspondence: Dr. B. S. Chaudhary Department of Geophysics Kurukshetra University, Kurukshetra 136 119, Haryana, India Telephone: 094163 36163, Fax: 01744238035 E-mail: bsgeokuk@gmail.com closely related are interchangeable. For example buildings/ settlement is cover but if we include whether it is being used for residence or industrial activity, it shows the land use component.

It is necessary to have accurate information about present land use/ land cover so as to prepare integrated plans for optimal utilization of natural resources in the region. In earlier days, information on land use/ land cover was generated through conventional ground survey methods which were not only time consuming, tedious, costly and man power demanding but also impractical for monitoring dynamic changes over a shorter period, due to subjectivity and time constraint. Satellite data with synoptic view, repetitive coverage and multispectral viewing etc has brought drastic changes in the land use/ land cover mapping and monitoring. The applications of remote sensing techniques are well established in land use/ land cover studies (Anderson, 1971, Anderson et al., 1976; Sinha et al., 1989; Hooda et al., 1992; Kushwaha and Oesten, 1995; Ram and Singh, 1995; Toleti, 1995; Hussin and Shaker 1995 Clevers et al., 1999; Chaudhary, 2003). 
The census of natural resources-land, water, soils, forests and other elements -conducted in a systematic manner with a repeat cycle to depict changes and modifications will provide the nation a "snap-shot" of the country's status of natural resources more or less on the similar approach of population census. Census can also have a broad definition of inventory with a systematic repeat cycle. "Natural Resources Census" (NRC) could start with the process of mapping and inventory using IRS images and generation of a national GIS repository. The subsequent cycles of the Census would enable a quick-change analysis and provide the nation a "State of Natural Resources Report". The Census would also be able to identify natural resources "hotspots "that are areas of rapid and deteriorating changes -calling for more detailed survey and investigations". The NR Census repository would contribute to the National Spatial Data Infrastructure (NSDI) as major content definition and would, hopefully, become the mainstay of the NNRMS programme for the coming years. Implementing the NR-Census poses a challenge and will call for an integrated effort of NNRMS with all its elements (State Centers, private sectors and the Central agencies) playing a role in tandem (NR-Census Guidelines, 2004). The present study has been carried out at the initiative taken by ISRO-NNRMS, Deptt. of Space, Government of India to understand the changing nature of the natural resources in northern part of Gurgaon District, India. The base information has been taken from 1996-97 satellite images and than comparison has been done with the satellite data of 2001-02 for various land use/ land cover categories. This change detection study will give definite base line information for the further actions to be taken by the line agencies for improving man-environment relationship.

\section{Objectives}

The study has been carried out with the following broad objectives:

Land use/ land cover mapping using 2001-02 digital satellite data

Digitization of existing land use/ land cover maps of 1996-97

Monitoring of land use/ land cover on 1:50,000 scale using 1996-97 and 2001-02 satellite data

Creation of digital database for national GIS repository.

Identification of the "hot-spots"

\section{STUDYAREA}

The study area lies in the northern part of Gurgaon district, Haryana and consists of Gurgaon and Sohna blocks. It lies between $28^{\circ} 11^{\text {' }}$ $\mathrm{N}$ and $28^{\circ} 32^{\prime} 25^{\prime}$ ' $\mathrm{N}$ latitudes and $76^{\circ} 52^{\prime} \mathrm{E}$ and $77^{\circ} 14^{\prime} 45^{\prime \prime}$ E longitudes and is bounded on the northwest by the Jhajjar district, Haryana on the north-east by the Union Territory of Delhi and on the east by Faridabad district of Haryana, on the south and west, the Nuh block and Farukhnagar block of the district marks the boundary respectively. Total area under study is about $697 \mathrm{sq}$. km. Location map of the study area is shown in figure 1 .

Physiographically, the study area comprises of hills on the one hand and depression on the other, forming irregular and diverse nature of topography. Sohna ridge forms the western boundary and the Harchandpur - Delhi ridge forms the eastern boundary of the area. These hills are the northern continuation of the Aravallies (District Gazeteer, Gurgaon, 1991). The north- western part of the area is covered with sand dunes, which lie in the direction of westerly and southwesterly winds. The drainage of the area is typical of the arid and semi-arid type. It comprises of large depressions and seasonal streams. Important depressions in the area are Damadama and Sulatanpur lakes. Geologically the area is occupied by Aravallis of Pre-Cambrian

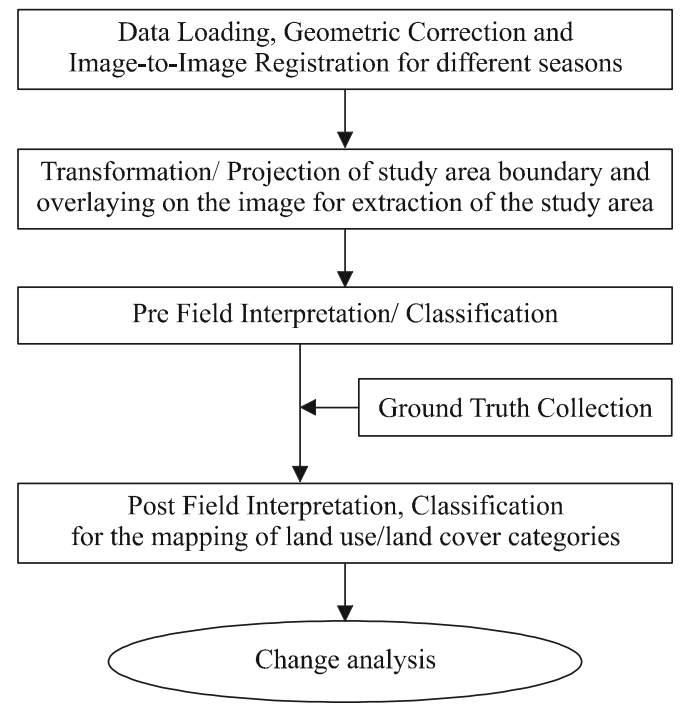

Fig. 1. Methodology Flowchart 
age and alluvium/ sand of recent to sub-recent origin. Pediments are found at places along the side of the Aravalli hills. Scattered isolated strike ridges of old rocks, the relicts of a former Aravalli mountain chain are found at places. The southwestern part of the area is covered by aeolian plain. Sand dunes are also observed at places.

The soil varies from sand to loamy sand in sand dunes and sandy plains, sandy loam to clay loam/ silty clay loam in alluvial plains, calcareous, loamy sand to loam in salt affected plains, silty loam to loam in low lands and calcareous, loamy sand to loam, in hills. Taxonomically, these are classified as Typic Ustipsamments, Typic Ustorthents, Typic Haplustepts, Typic Epiaquepts and Lithic Ustorthents (Arya et al., 1999).

The area experiences dry weather with hot summer and cold winter except during the monsoon. The normal annual rainfall is $665.2 \mathrm{~mm}$. About 77 per cent of annual rainfall is received during the monsoon months i.e. July to September. Temperature starts rising in March. The mean daily maximum temperature is about $41^{\circ} \mathrm{C}$ in the months of May and June. It may go up to $45^{\circ} \mathrm{C}$ or more in June. During winter the mean daily maximum temperature in January is $21^{\circ} \mathrm{C}$ and minimum is about $7^{\circ} \mathrm{C}$ (Statistical Abstract, Haryana, 2001-2002).

\section{DATA BASE AND METHODOLOGY}

IRS-IC/ID LISS-III digital data of August/ September 2001, February 2002 and June 2002 were used along with IRS 1B LISS II satellite data (paper prints) of August 1996 and February 1997. The data therefore represents both rabi and kharif seasons. Ancilliary data also aided the analysis in updating the information. In particular, topographical maps formed the basis for annotating various built up features.

The methodology involved digital classification of IRS digital data and online digitization of interpreted maps. The digital data was preprocessed and geo-referenced to help overlay datasets of two different dates to study land use/ land cover change.

The digital classification was based on the widely popular supervised classification technique, the maximum-likelihood classifier. This needed a number of training sites for all the classes spread across the study area to capture spectral variability. Separability analysis were undertaken using diversion matrix on training data to understand the separability between different classes in spectral space. The confusion matrix was derived for digital analysis of LISS III data.

Classified data of both rabi and kharif season were combined using an appropriate model. The model was based on the logic and helped in combining classes of both rabi and kharif season. The raster output of digital classification was converted into vectors to compute statistics of various classes in Arc/Info GIS. The combination of two data sets resulted in small polygons called slivers which were removed to smoothen the final map. Land use change for two periods were finally derived by intersecting the thematic maps of the two periods 1996-97 with 2001-02. The methodology flowchart is shown in figure 2 .

\section{RESULTS AND DISCUSSION}

Land is one of the most important natural resources. All agricultural, animal and forestry productions depend on the productivity of the land. The entire eco-system of the land, which comprises of soil, water and plant, meets the community demand for food, energy and other needs of livelihood. The prime requisite for better land use planning is information on existing land use and their spatial distribution as they are important to determine land use policy, planning of transportation and communication services etc. The present land use is related to landform, soil conditions, irrigation facilities, marketing and socio-economic conditions. Area under various land use classes and changes over a period of five years are given in the Table 1. The land use/ land cover maps of the area for the year 1996-97 and 2001-2002 are shown in Figure 3 where as land use / land cover change map during the period of investigation is shown in figure 4 .

\section{Land Use/ Land Cover Change Assessment}

\section{Built-up Land}

Built-up land is an area of human habitation, which has a cover of buildings and network of transport, and other civic amenities. Total area under towns/ cities have increased from $26.58 \mathrm{sq}$ $\mathrm{kms}$ in $1996-97$ to $124.15 \mathrm{sq} \mathrm{kms}$ in 2001-02. This is due to urban expansion of Gurgaon town and Manesar township. 


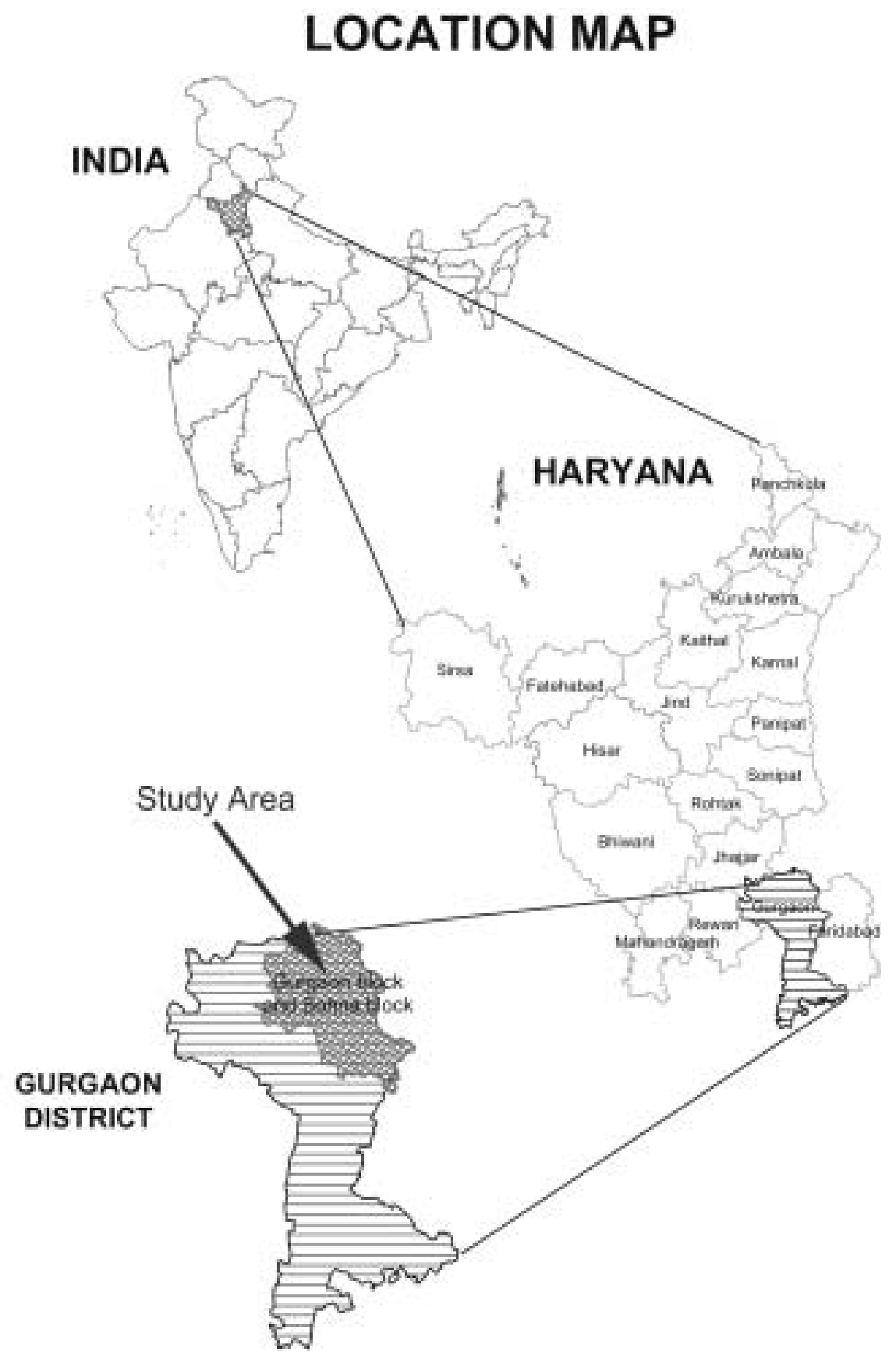

Fig. 2. Location map of study area 
Table 1: Land use / land cover distribution and change area statistics

\begin{tabular}{|c|c|c|c|c|c|c|c|}
\hline $\begin{array}{l}S . \\
N o\end{array}$ & & Class & & Symbol & $\begin{array}{l}\text { Area } \\
1996-97 \\
(\mathrm{sq} . \mathrm{km})\end{array}$ & $\begin{array}{l}\text { Area } \\
2001-02 \\
(s q . \mathrm{km})\end{array}$ & $\begin{array}{l}\text { Change } \\
(s q . k m)\end{array}$ \\
\hline \multirow[t]{3}{*}{1} & Built-Up Land & Towns/Cities & & 1 & 26.58 & 124.15 & $97.57(14.00)$ \\
\hline & & & Recreational & 40 & 0.00 & 1.32 & $1.32(0.19)$ \\
\hline & & Villages & & 2 & 9.38 & 11.17 & $0.79(0.26)$ \\
\hline \multirow[t]{4}{*}{2} & Agricultural Land & Crop Land & Kharif & 3 & 5.72 & 14.73 & $9.01(1.29)$ \\
\hline & & & Rabi & 4 & 82.27 & 118.40 & $36.13(5.18)$ \\
\hline & & & Double Cropped & 5 & 279.55 & 236.52 & $-43.03(-6.17)$ \\
\hline & & Fallow & & 6 & 0.52 & 7.49 & $6.97(1.00)$ \\
\hline \multirow[t]{5}{*}{3} & Forest & Deciduous & Closed & 10 & 0.12 & 25.59 & $25.47(3.65)$ \\
\hline & & & Open & 11 & 129.01 & 92.20 & $-36.81(-5.28)$ \\
\hline & & Scrub Forest & & 12 & 1.10 & 7.88 & $6.78(0.97)$ \\
\hline & & Forest Blanks & & 13 & 0.29 & 0.68 & $0.39(0.06)$ \\
\hline & & Forest Plantations & & 14 & 18.99 & 13.54 & $-5.45(-0.78)$ \\
\hline \multirow[t]{6}{*}{4} & Wastelands & Salt Affected & & 16 & 1.05 & 1.13 & $0.08(0.01)$ \\
\hline & & Waterlogged & & 17 & 1.77 & 1.56 & $-0.21(-0.03)$ \\
\hline & & Gullied/ Ravinous Land & & 19 & 3.08 & 2.77 & $-0.31(-0.04)$ \\
\hline & & Scrub Land & & 20 & 130.72 & 32.44 & $-98.28(-14.10)$ \\
\hline & & Sandy Area & & 22 & 1.19 & 1.50 & $0.31(0.04)$ \\
\hline & & Mining Waste & & 23 & 1.38 & 0.71 & $-0.67(-0.10)$ \\
\hline 5 & Water Bodies & Lakes/ Ponds & & 25 & 2.49 & 1.91 & $-0.58(-0.08)$ \\
\hline \multirow[t]{2}{*}{6} & Others & Degrade Pasture/ Grazing & Land & 27 & 1.82 & 1.34 & $-0.48(-0.07)$ \\
\hline & & & & & 697.03 & 697.03 & \\
\hline
\end{tabular}

Note: The figures given in Parenthesis are \% change in the land use categories.

\section{Agricultural Land}

The land primarily used for farming and for production of food, oil seed and other commercial and horticultural crops comes under this category. This area is further divided into different categories such as rabi crop, kharif crop, double crop and fallow.

Kharif: Kharif season crops include all the agricultural crops, which are harvested between June to October. The major kharif crops grown in the area are jowar, bajra and paddy under food grain crops and bajra and jowar as fodder crops. This unit covered an area of 5.72 sq. $\mathrm{kms}$ and 14.73 sq. kms during 1996-97 and 2001-02 respectively. More area under kharif during 200102 may be due to good rainfall during 2001-2002.

Rabi: Rabi season crops include those agricultural crops, which are harvested between March and April. Rabi crops are mainly wheat and mustard and to some extent chickpea and vegetables. The areal extent of this unit was 82.27 sq kms in 1996-97 and $118.40 \mathrm{sq} \mathrm{kms} \mathrm{in} \mathrm{2001-02.}$ This increase in rabi crop area in 2001-02 may be due to good rainfall and availability of canal water during 2001-2002.

Double Cropped Area: This is the intensive cultivated area which is used for raising both rabi and kharif crops. The double cropped area has decreased from 279.79 to $236.52 \mathrm{sq} \mathrm{kms}$ within a period of five years.

Fallow: The land, which is temporarily lying vacant in both kharif and rabi seasons due to one or the other reason, is called fallow land. Fallow lands could be delineated by using two seasons data, i.e., kharif and rabi. The area has increased from 0.52 to $7.49 \mathrm{sq} \mathrm{kms}$.

\section{Forest}

Forest is defined as all land bearing vegetative association dominated by trees of any size, capable of producing wood or other forest products and exerting an influence on climate or water regimes or providing shelter for wild life and live stock (FAO, 1981). Aravalli, one of the oldest hill ranges of the world, passing through this area is the main forest resource for this area. Forest is divided into different sub categories, viz., dense forest, open forest, scrub forest, forest blanks, forest plantations etc.

Closed or Dense Forest: If the crown cover is more than $40 \%$ of the area then the area is divided into dense forest area. This class did not exist in 1996-97 but due to the extensive efforts by the forest department for the regeneration of the forest, this category has increased from 0.12 sq kms in 1996-97 to $25.59 \mathrm{sq} \mathrm{kms} \mathrm{in} \mathrm{2001-2002.}$ 
Landuse/Land Cover Map 1996-97

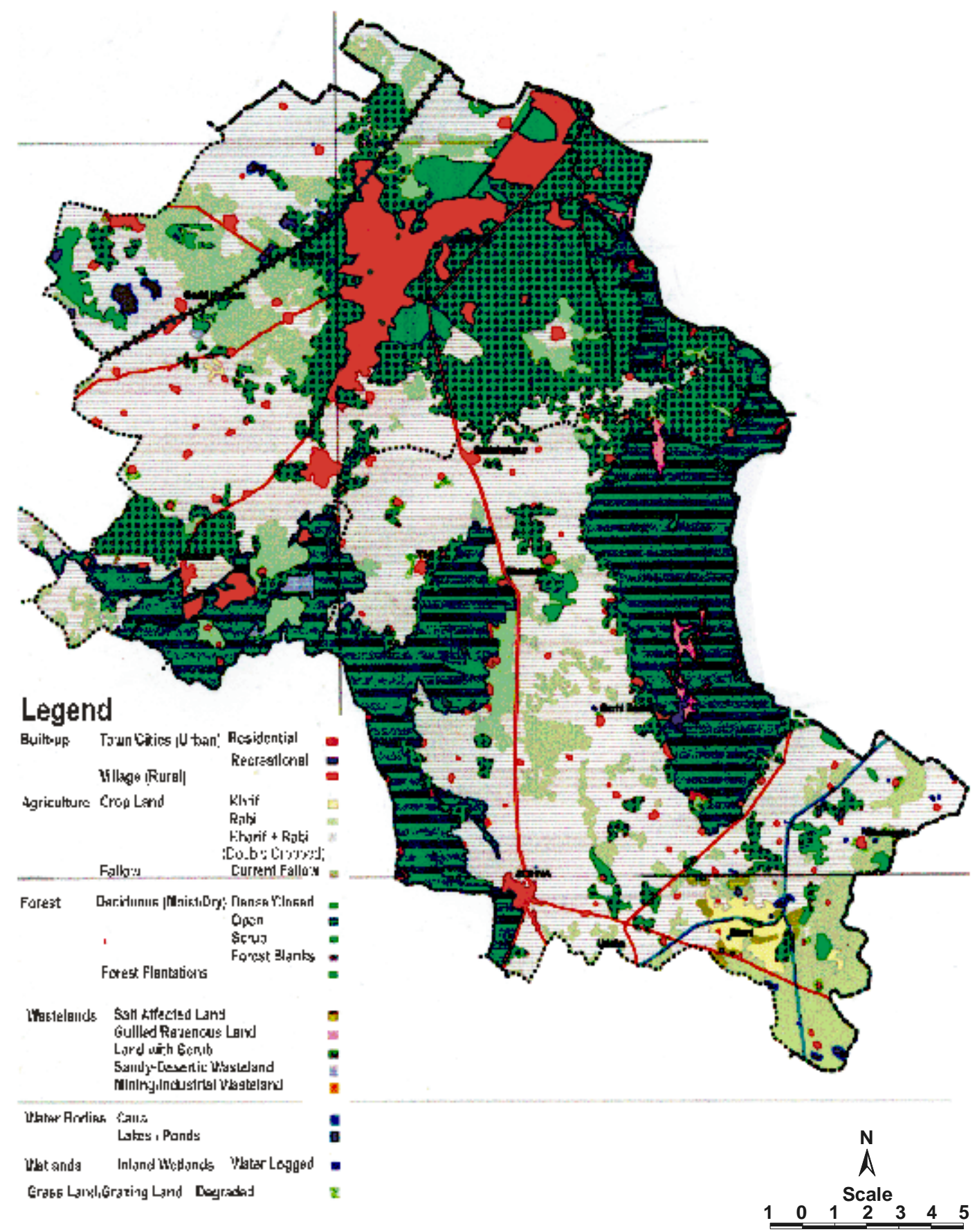

Fig. 3a. Land use/ land cover status during the years 1996-97 and 2001-02 

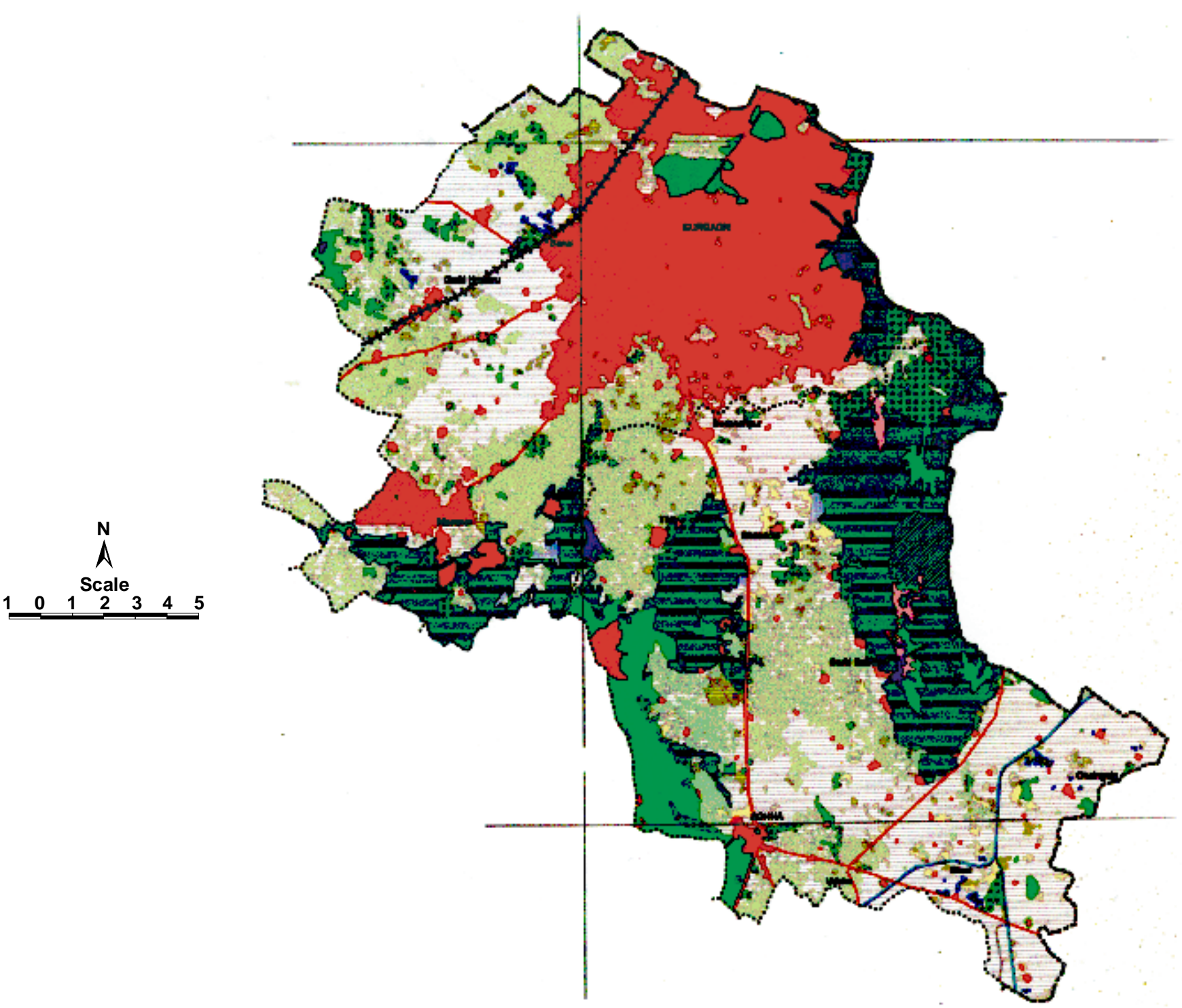

Fig. 3b. Land use/ land cover status during the years 1996-97 and 2001-02 


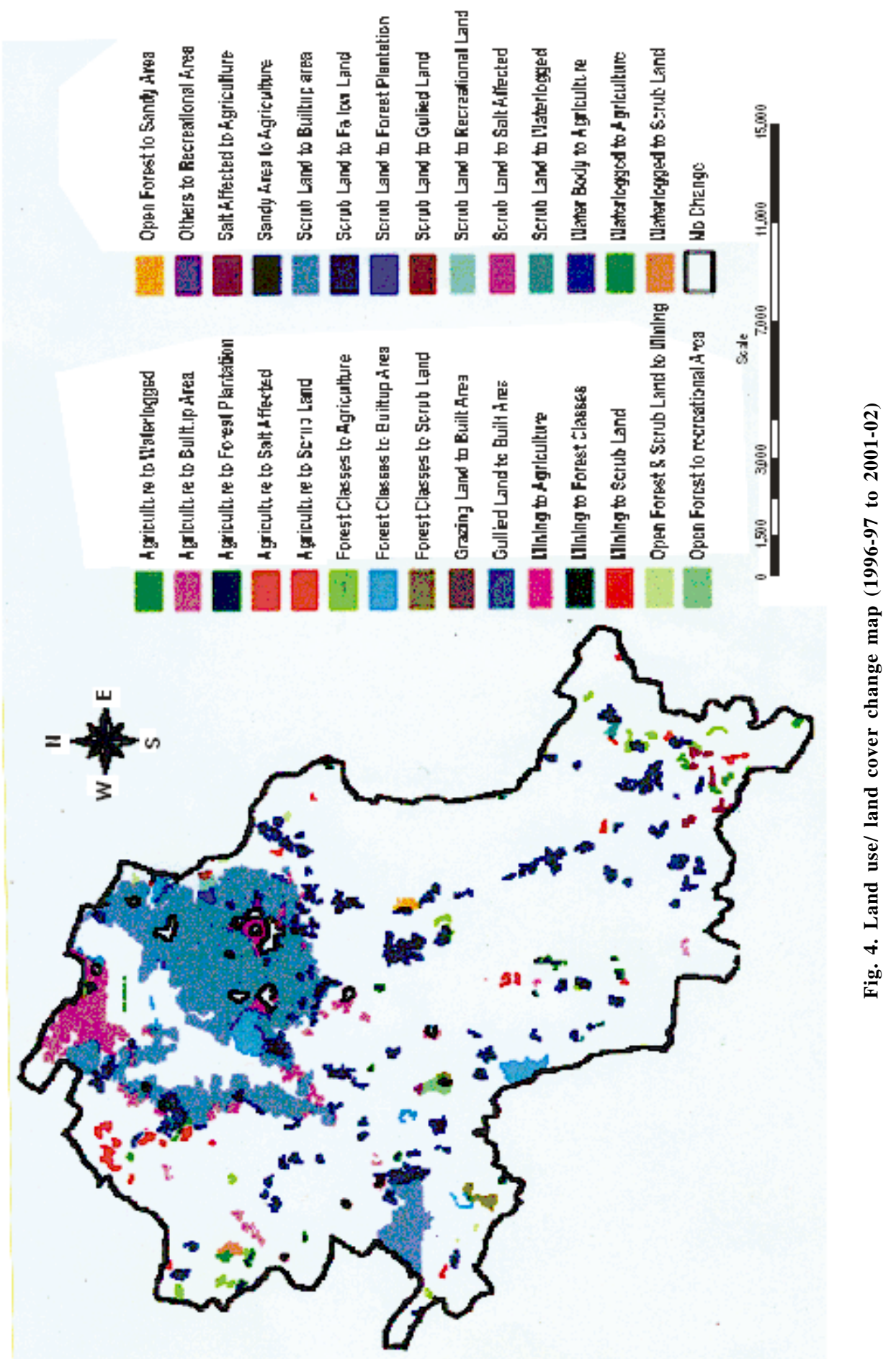


Open Forest: If the crown cover of the area is less than $40 \%$ and more than $10 \%$, i.e., between 10 to $40 \%$ of the area, then the forest is classified under open forest. As lot of area has gone to the closed forest category, the areal extent of this class has decreased from 129.01 in 1996-97 to 92.20 sq kms in 2001-2002.

Scrub Forest: The area covered with mixture of scrub and bush type of forest species is classified under this category. The area has increased from 1.10 in 1996-97 to $7.88 \mathrm{sq} \mathrm{kms}$ in 2001-02. This increase is not due to degradation in the forest area but scrubland has converted in to scrub forest category.

Forest Blanks: The areas devoid of plants in the notified forest areas were categorized as forest blanks. This may be due to fire damage or illegal occupation by civilians' etc. The area has increased from 0.29 to $0.68 \mathrm{sq} \mathrm{kms}$ over a period of five years.

Forest Plantations: Forest department has taken many steps to protect or to improve the forest lands. For this purpose forest department has planted different species of plants, viz., Acacia nelotica, Excelsa airthus, Tartallis sp., Eucalyptus sp. etc. The notified forest areas were also put under this class. The area under this category has decreased from 18.99 to $13.54 \mathrm{sq}$ kms during the period from 1996-97 to 2001-02.

\section{Waste Lands}

Wastelands are those lands, which are currently unutilized or under utilized and can be brought under vegetation cover/ cultivation with reasonable efforts. The wastelands in the area are salt affected lands, water logged land, gullied land, land with or without scrub, mining or industrial waste land and barren rocky/stony waste land as given below.

Salt Affected Land: The salt affected land is generally characterized as the land that had adverse effects on the growth of most of the plants, due to presence of excess soluble salts. Even though, majority of the area has been brought under cultivation in due course of time after reclamation, still some new areas have come up in this category. There is very marginal change in the salt affected area. It increased from 1.05 to 1.13 sq. $\mathrm{km}$ during the priod under investigation.

Water Logged Land: The land, which is covered with water for most of the year was classified as water-logged. Surface water logged land is the land, where the water is at/or near the surface. The Water logging in the area is the result of canal seepage and accumulation of water in local depression. Whenever the area experiences heavy rainfall, it becomes water logged in the localised depressions. The area under this class has decreased from 1.77 to 1.56 sq $\mathrm{kms}$ during this period.

Gullied Land: Gullies are narrow and deep channels developed as a result of erosion of soil by running water. They are more common on sloping surface. This area has also decreased from 3.08 to $2.77 \mathrm{sq} \mathrm{kms}$ during the period from $1996-97$ to 2001-02. This class is found in the foothills.

Land With or Without Scrub: Sand dunes at some places are covered with wild Saccharam sp. and areas adjoining to hills were also included under this category. There was a very large area in the vicinity of Gurgaon city during 1996-97 under this category. In the year 2001-02, most of this category has been converted to built up land. Therefore, the area under this category has decreased from 130.72 to $32.44 \mathrm{sq} \mathrm{kms.}$

Mining/Industrial Wasteland: This unit includes the areas where active quarrying is going on. The areas of sand-mining activity are also included in this category. The mining activity is observed more on Aravalli hills. Total area under mining has decreased from $1.38 \mathrm{sq} \mathrm{kms}$ to $0.71 \mathrm{sq}$ $\mathrm{kms}$ over a period of five years.

\section{Water Bodies}

The village ponds, lakes, reservoirs and man made tanks are included in this category. The area under this class has decreased from 2.49 to $1.91 \mathrm{sq} \mathrm{kms}$ during the period of investigation.

\section{Degraded Pasture/ Grazing Land}

The areas around the villages, which are left for animal sheltering are included in this category. These lands are also meant for cattle grazing purpose. These are mostly village common lands or panchayat lands. This class has decreased from 1.82 to $1.34 \mathrm{sq} \mathrm{kms.}$

\section{Hot Spots}

Hot spots are the areas that are undergoing rapid changes. During the study it was found that Gurgaon city is expanding alarmingly at the 
cost of scrubland and agricultural area. Around Gurgaon city, a number of Golf courses and other recreational centres are also coming up which are encroaching even forest areas. Manesar township is also growing very fast. It is observed that some areas on the western hills are being urbanized, encroaching the forest, which will have an adverse effect on the environment.

\section{CONCLUSIONS}

It is interesting to see the influence of human activities on the natural resource of the area. It is clear from the above study that there is remarkable increase in urban area. The expansion of Gurgaon City is due to increasing population and Industrial/Infrastructural development pressure of National Capital, as Guragon is the most preferred and favourable destination. The main reasons behind it are its location, availability of outstanding facilities, law and order situation etc. Haryana Urban Development Authority (HUDA) has developed very well organised modern sectors for industrial/ commercial/ residential purposes. The expansion of Sohna and Manesar towns was also at faster rate during this period. The expansion of urban area is mainly at the cost of Scrubland. There is an increase in the area of closed forest category as a result of environmental awareness and funding provided by the European Commission and State Govt. for the regeneration of Forest on Aravalli hills. The extensive efforts of Department of Forest have resulted in the conversion of scrub and open forest in to closed forest areas.

\section{REFERENCES}

Anderson, J. R.: Land use classification schemes used in selected recent geographic applications of remote sensing. PE and RS, 37(4): 379-387 (1971).
Anderson, J.R., Hardy, E.E., Roach, J.T. and Witmer, R.E.: A Land use and land cover classification system for use with remote sensor data. Geological Survey Professional Paper 964, U. S. Govt. Printing Office, Washington (1976)

Arya, V.S., Sultan, S., Chaudhary, B.S., Kumar, Ashok, Toleti, B. V. M. Rao: Mapping of soil and water resources of Mewat area: Problems and their management using remote sensing techniques. Technical Report, HARSAC/TR/ 25/99 (1999).

Chaudhary, B.S.: Integrated Land and Water Resources Management in Southern Part of Haryana Using Remote Sensing and Geographical Information Systems (GIS). Ph. D. Thesis (Unpublished), University of Rajasthan, Jaipur (2003).

Clevers, J.G.P.W., Muecher, C.A., Popov, V. P. Vandysheva, N.M. and Vassilenko, G.I.: Agriculture land cover monitoring over Russia using remote sensing. Proc. $18^{\text {th }}$ EARSeL Symp. ITC, Enschede, the Netherlands, A. A. Balkema, Publishers Rotterdam (1999).

District Gazeteer, Gurgaon (1991).

Hooda, R.S., Manchanda, M.L. and Sharma, J.R.: Digital analysis of IRS - 1A LISS I data for land use/ land cover mapping in Haryana State. In: NNRMS - A New Perspective, R.L. Karale (Ed.). ISRO-NNRMS, Bangalore (1992).

Hussin,Y. A. and Shaker, S. R.: Monitoring the changes in the tropical forest land use by remote sensing and GIS. Proceedings IUFRO XX World Congress, Tampere/Finland, August, 6 to12, 1995, (1995).

Kushwaha, S.P.S and Oesten, G.: A rule based system for forests land use planning. Photonirvachak, 23(3): 115-125 (1995).

NR-Census Guidelines, 2004, SAC Ahmedabad.

Ram, B. and Singh, S.: Remote sensing in sustainable land use planning. Paper presented in National Symposium on Remote Sensing of Environment at Punjab Remote sensing Application Centre in PAU, Ludhiana, Pp. 189-195 (1995).

Sinha, B.K., Kumar, Ashok, Srivastava, Deepak and Kumar, Sanjay: Integrated approach for tube well site location in problem areas- a case study near village Chitab, Gaya District, Bihar. Proc. National Symp. on Engineering Applications of Remote Sensing and Recent Advances, Indore, Pp. 35- 40 (1989).

Statistical Abstract of Haryana, (2001-2002).

Toleti, B.V.M. Rao: A Study on Impact of Coal Mining on Land Use and Land Cover in Jharia Coalfield (Dhanbad) India Through Remote Sensing Technique. Ph.D. thesis (Unpublished), Indian School of Mines, Dhanbad, India (1995). 